\title{
Tanda-tanda Suatu Sistem Pendidikan Akan Gagal
}

\begin{abstract}
Ahmad Ainul Yaqin
Setiap orang pasti berpikir persis apa yang terjadi pada bangsa ini. Sehingga bangsa Indonesia tidak bangga dengan statusnya sendiri. Segudang masalah menimpa bangsa ini: terorisme yang merajalela, hukum yang tidak jelas, kejahatan di mana-mana, premanisme, kemiskinan yang meningkat, konflik yang terus-menerus, pornografi yang mengakar, dan korupsi yang membabi buta. Pertanyaannya adalah mengapa semua ini terjadi? Bukankah kita sudah melakukan pendidikan moral dan pendidikan karakter? Lalu, bagaimana menjelaskan tindakan-tindakan di atas yang harus dilakukan oleh orang-orang terpelajar, dari institusi dan institusi yang dihormati di negeri ini?
\end{abstract}

Faktor yang paling mendasar tentunya adalah kegagalan sistem pendidikan kita untuk menghasilkan pemimpin yang jujur dan bawahan yang patuh. Setidaknya kita bisa melihat bahwa ada kesalahan sistem dalam penyelenggaraan pendidikan sehingga semangat pendidikan tidak sampai kepada peserta didik. Hal inilah yang memicu terjadinya krisis multidimensi di negeri ini karena krisis hebat yang melanda bangsa ini justru bermuara pada nilai moral yang rendah.

Ada yang menarik dari masalah pendidikan di negeri ini. Bagaimana soal soal ujian nasional bisa didistribusikan ke daerah oleh pemerintah pusat di bawah pengawasan polisi. Begitu buruknya moral bangsa ini sehingga di lembaga pendidikan nampaknya nilai kejujuran sangat langka. Bagaimana mungkin pemberantasan korupsi bisa, padahal lembaga yang menjadi sumber kejujuran dan karakter begitu rapuh. Belum lagi masalah seperti tingginya angka kriminalitas, pergaulan bebas di kalangan remaja dan masih banyak masalah hukum lainnya. Lantas, siapa yang seharusnya salah posisi dalam pertanyaan di atas? Menjawab pertanyaan ini tentunya sangat sulit dan setiap pihak yang dituduh pasti akan membela diri dengan menawarkan beberapa pembelaan. Mengenai krisis moral yang melanda negeri ini setidaknya kita bisa melihat bahwa ada faktor-faktor utama yang kemudian diikuti oleh faktor-faktor dan variabel-variabel yang semuanya perlu diperbaiki dan perlu perbaikan. Faktor utamanya adalah kegagalan sistem pendidikan kita dalam membentuk manusia yang cerdas, beriman, bertakwa, dan berbudi luhur, sesuai amanah. Kemudian faktor ini diikuti oleh pemicu lingkungan yang tidak mengajarkan nilainilai moral dan kurangnya penyaringan informasi dan budaya yang masuk ke Indonesia.

Itulah jawaban tentang siapa yang harus bertanggung jawab atas kemerosotan moral bangsa ini. Yang paling bertanggung jawab adalah institusi pendidikan, bukan hanya sistem yang dijalankan tetapi semua elemen yang bekerja dalam dunia pendidikan. Hingga saat ini upaya pembentukan akhlak mulia di sekolah belum pernah dilakukan. Namun pendidikan moral dan moral hanya bersifat teoritis dan berilmu, seperti yang tertuang dalam PKn dan studi agama. sangat melekat dengan karakter siswa. Selain itu, standar kelulusan dalam pendidikan moral hanya diukur dari bagaimana anak dapat menghafal, menganalisis dan mampu menjawab soalsoal ujian, sedangkan karakter dan perilaku anak belum menunjukkan keberhasilan proses pembelajaran. Sistem yang demikian berdampak pada perilaku anak sehingga terjadi kesenjangan antara pengetahuan moral dan perilaku. Pendidikan akhlak belum menyentuh karakter mereka sehingga tidak membentuk pola pikir dan perilaku mereka menjadi lebih bermoral. Hal ini dikarenakan seseorang dapat disebut sebagai orang yang berakhlak baik jika perilakunya sesuai dengan kaidah moral, baik dalam ajaran agama maupun dalam norma sosial.

Kemudian lemahnya proses pendidikan akhlak diperparah dengan lingkungan sekitarnya yang seolah tidak mendukung mereka untuk menjadi orang yang baik. Penayangan sinetron yang tidak terkendali, penyebaran video porno yang tidak terkendali di beberapa situs internet, hingga kurangnya pengawasan orang tua terhadap anak. Eksploitasi masif oleh media dengan pemberitaan pejabat korup, artis yang terlibat narkoba, kejahatan seksual dan pejabat yang menyoroti konflik membuat anak kehilangan sosok yang seharusnya bisa mereka tiru. Akibatnya, masyarakat mulai mengabaikan norma dan nilai agama sehingga memicu krisis moral yang lebih cepat 
Parahnya, pengaruh teknologi begitu mencekam seperti ponsel dengan fitur internet atau kamera, sehingga memudahkan anak-anak mengakses gambar pornografi atau kekerasan. Apalagi dengan maraknya warung internet yang tidak membatasi akses untuk anak-anak. Lalu, banyak orang tua yang tidak mau tahu. bisnis putranya. Mereka memberikan keleluasaan penuh kepada anaknya untuk memegang ponsel. Namun seberapa pentingkah penggunaan ponsel oleh anak usia sekolah? Bahkan bisa membuat anak-anak tumbuh besar dengan kebebasannya menggunakan ponsel di luar kebiasaan dengan menyimpan video porno dan hal-hal mesum lainnya. Rata-rata jumlah kasus kejahatan seksual yang dilakukan oleh anak usia sekolah karena ingin meniru adegan pornografi yang tersimpan di ponselnya. Terkadang mereka merekam video mesum tentang apa yang mereka lakukan hingga membuat heboh di media massa. Apalagi tingkat kesadaran masyarakat terhadap lingkungannya sudah mulai menurun. Mereka tampaknya tidak peduli dengan apa yang dilakukan anak-anak di sekitar mereka, karena mereka mungkin sibuk dengan urusan mereka sendiri atau takut dengan pembelaan orang tua ketika anak tersebut ditegur.

Hal ini kemudian menyebabkan hampir semua aspek kehidupan sosial mengalami penyimpangan karena tercemar oleh cara hidup masyarakat yang tidak benar sehingga penyimpangan menjadi kebiasaan, bukan kesalahan. Akhirnya seorang anak lepas kendali sehingga degradasi moral berupa perbuatan asusila dianggap wajar. Tradisi asusila berupa arogansi dan kenakalan remaja dianggap wajar. Mengakui tindakan menyimpang masyarakat terkadang meminta maaf pada waktunya

Dengan demikian, penyelesaian krisis moral ini tidak bisa dilakukan oleh lembaga sekolah saja, melainkan membutuhkan gerakan dari banyak pihak, pengelola lembaga pendidikan, pemerintah, tokoh agama, orang tua dan masyarakat. Semuanya harus bergerak dalam suatu gerakan yang dapat menimbulkan persepsi bahwa nilai moral lebih tinggi dari sekedar pengetahuan. Menanamkan persepsi seperti ini tentunya harus dimulai dari sekolah yang kemudian diperkuat dengan kepedulian masyarakat terhadap lingkungan sekitar.

Oleh karena itu, guru dituntut tidak hanya memiliki kompetensi, keterampilan dan kemampuan yang tinggi serta penguasaan bahan ajar, tetapi juga memiliki keunggulan lain di bidang pembinaan moralitas dan nilai-nilai etika. Dalam matematika misalnya, tidak hanya fokus pada objektivitas angka, tetapi juga mengajarkan bagaimana karakter menjadi benar dengan nilai kejujuran. Sehingga seorang anak tidak hanya tumbuh dengan ilmunya yang cerdas, tetapi juga tidak mudah bermain-main dengan angka yang berujung pada korupsi dan penipuan.

Kemudian pembibitan di sekolah didampingi oleh masyarakat, sesuai dengan tugas dan fungsinya masing-masing. Pemuka agama bertugas memberikan arahan kepada masyarakat mengenai akhlak dan etika, orang tua mengawasi perilaku anak di rumah, dan pemerintah mengeluarkan peraturan yang mengatur perilaku masyarakat yang berpihak pada adat istiadat nasional dan tatanan moral. Misalnya dengan membatasi penggunaan ponsel untuk anak usia dini, misalnya hingga jenjang SMA, memilih acara televisi yang tidak mendidik. Insan pers, khususnya televisi, bertugas menyajikan program-program edukasi, tidak hanya siaran tetapi juga pembinaan. Namun persoalan budaya dan moral adalah segalanya sehingga tidak bisa dikaitkan dengan masalah bisnis semata. Cerita yang mengandung pergaulan bebas, perkelahian antar geng, kenakalan saat belajar di sekolah, pergaulan bebas dan perzinahan, perilaku tidak hormat terhadap guru dan orang tua, budaya kekerasan dan penganiayaan, menonjolkan rasa iri dan iri hati serta perilaku licik merupakan tema yang tidak boleh disiarkan karena dapat menenangkan dan menggeser nilai budaya dan moral masyarakat. Upaya guru di sekolah dalam membentuk karakter siswa akan segera runtuh ketika anak-anak memperhatikannya. Artinya, kewajiban moral bangsa membutuhkan kerja sama antar seluruh elemen bangsa. Tanpa kerjasama, pendidikan moral dan etika yang diberikan di sekolah akan sulit berhasil. Bagaimana sebuah struktur moral bisa berdiri dengan megah dan indah ketika orang yang peduli mencoba memperbaikinya sementara yang lain terus membongkar! 


\section{References}

As'ari, A R, Tohir, M., Valentino, E., Imron, Z., \& Taufiq, I. (2016). Matematika untuk SMP. MTs Kelas VII Semester, 1.

As'ari, Abdur Rahman, Tohir, M., \& Valentino, E. (2017). Matematika-Kelas VIII SMP/MTsSemester 1. Jakarta.

As'ari, Abdur Rahman, Tohir, M., Valentino, E., Imron, Z., \& Taufiq, I. (2016). Buku Guru Matematika untuk SMP/MtS Kelas VII. Jakarta: Kemdikbud.

Hidayat, R., \& Patras, Y. E. (2013). Evaluasi sistem pendidikan nasional Indonesia. 2nd International Seminar on Quality and Affordable Education (ISCAE), 235-244.

Megawanti, P. (2015). Meretas Permasalahan Pendidikan Di Indonesia. Formatif: Jurnal Ilmiah Pendidikan MIPA, 2(3).

Munirah, M. (2015). Sistem Pendidikan di Indonesia: antara keinginan dan realita. AULADUNA: Jurnal Pendidikan Dasar Islam, 2(2), 233-245.

Pendidikan, K., \& Indonesia, K. R. (2014). Matematika SMP/MTs Kelas VIII Semester 1. Jakarta Kementrian Pendidik. Dan Kebud.

Penulis, T. (2014). Matematika Buku Guru, Kurikulum 2013, Edisi Revisi 2014. Kementerian Pendidikan Dan Kebudayaan, p311-353.

Tohir, M. (2016). Hasil PISA Indonesia tahun 2015 mengalami peningkatan. Jurnal Researchgate.(1-2).

Tohir, M. (2019a). Hasil PISA Indonesia tahun 2018 turun dibanding tahun 2015. Paper of Matematohir.

Tohir, M. (2019b). Sosok Guru Profesional yang Ideal Ala Ki Hajar Dewantara. Paper of Matematohir.

Tohir, M., \& Wardani, A. W. (2019). Analysis of Prospective Mathematics Teachers Ability in Applying Scientific Approach Based The Curriculum 2013. Proceedings of The National Seminar on Mathematics Education. 